\title{
Biserica Ortodoxă și societatea occidentală, între mărturisire duhovnicească și progres tehnologic. Reflecții pe marginea pandemiei Covid 19
}

\author{
Alexandru OJICA $\breve{A}^{*}$
}

Abstract: The Orthodox Church and Western society, between spiritual confession and technological progress. Reflections on the Covid19 pandemic. The pandemic caused by Covid19 highlighted once again the deficiencies in the state-church relationship. In addition to the fact that among Christians there are mentalities such as those expressed by Yuval Harari - especially about the role of religions in society, an excessive secularization of religious sentiment, the Orthodox Church also faces problems caused by excessive digitization, addictions caused by the use of new technologies and Artificial Intelligence.

Keywords: Orthodox Church, Artificial Intelligence, Covid19, StateChurch, Transhumanism.

La întreg nivelul Bisericii Ortodoxe ${ }^{1}$, în ultimul secol, au avut loc numeroase întâlniri care au reflectat viziunea Ortodoxiei

* Doctor în Teologie al Facultăţii de Teologie Ortodoxă „Justinian Patriarhul”, Universitatea din București, România.

1 In vasta bibliografie pe acest subiect amintim printre altele: Viorel IONIȚĂ, Hotărârile întrunirilor panortodoxe din 1923 până in 2009. Spre Sfântul și Marele Sinod al Bisericii Ortodoxe, București, Edit. Basilica a Patriarhiei Române, 2013, p. 264; IDEM, Sfantul și Marele Sinod al Bisericii Ortodoxe Documente pregătitoare, București, Edit. Basilica a Patriarhiei Române, 
atât la nivel local, cât și la nivel internațional. Subiectele discutate nu au fost doar cele care aveau o tangență strict internă - post, căsătorie, dialogul inter-ortodox etc., ci s-a pus în discuţie şi rolul Bisericii Ortodoxe în societate și în lume. Intâmplările din anul 2020, pandemia cauzată de virusul Covid19, au reflectat noi provocări la adresa Bisericii Ortodoxe, nu doar în ceea ce privește rolul ei în societate, ci și la nivel intern, în fața credincioșilor. Lesne se ridică întrebarea: Care mai e rolul unei Biserici în societate din moment ce nu își poate primi credincioșii la slujbă? Biserica, înțeleasă ca fiind extensia trupului lui Hristos cel Înviat, are un caracter divino-uman. Făcând parte din societate prin credincioșii ei, Biserica a trebuit să ofere un răspuns provocărilor și crizelor prin care lumea și civilizațiile, indiferent de epocă, au trecut. Pricipalele provocări din societatea contemporană la adresa Bisericii Ortodoxe sunt: relația cu statul, impactul pe care noile tehnologii (numite generic Inteligența Artificială) le au în viața credincioșilor și unele practici din domeniul bioeticii care contravin flagrant învăţăturii și moralei ortodoxe în cazul de față. De menționat este faptul că aceste provocări existau deja, după cum vom avea, pandemia având mai mult rolul de catalizator al acestor provocări.

Analizând istoria din punct de vedere teologic, Pierre Grelot amintea în anii 1960, printre altele că: „Civilizațiile rafinate, aparent apropiate de o reușită excepțională, sunt brusc invadate de o decadență ireparabilă care le dezumanizează membrii și sunt urmate de regresii nu mai puțin spectaculoase"2. Pentru Grelot rana umanitătii înțelese doar din perspectivă istorică este una evidentă pentru că pune în lumină contradicțiile progresului uman și tragismul istoriei. Civilizațiile pier, iar decadența și finalul lor par mai mult o sinucidere decât o moarte de bătrânețe.

2016, p. 174; *** Pentru viața lumii. Către un ethos social al Bisericii Ortodoxe: invătătura socială a Bisericii Ortodoxe în viziunea Patriarhiei Ecumenice, trad. Viorel Coman și Petre Maican, Oradea, Edit. Ratio et Revelatio, 2020, p. 140.

2 Pierre Grelot, Sens chrétien de l'Ancien Testament. Esquisse d'un traité dogmatique, $2^{\mathrm{e}}$ édition, revue et corrigée, Paris, Éditions Desclée et Cie, 1962, p. 107-108. 
Această moarte a civilizației europene așa cum o știm noi trebuie văzută în cheia Omului recent și a vieții în postmodernitate ${ }^{3}$. Filosoful român Horia-Roman Patapievici considera că „modernitatea este rea când, dintr-o tehnică, este transformată într-o teologie. Este bună când e tratată în datele ei «naturale»""4. Tot Patapievici, dar într-o analiză mai recentă, descria relația dintre Europa și creștinism ca fiind asemănătoare cu cea dintre corp și suflet ${ }^{5}$. În schimb, Yuval Noah Harari, dimpotrivă, consideră că religiile tradiționale (aici fiind vizată în primul rând creștinismul) sunt o parte a problemei omenirii și datorită atitudinii lor fată de noile tehnologii ${ }^{6}$. Insă atitudinea creștină față de ceea ce înseamnă progres tehnologic a fost exprimată încă din secolul trecut, chiar în timpul

${ }^{3} \mathrm{Nu}$ am greși dacă această postmodernitate ar fi numită după cartea lui Mario Vargas LlosA, Civilizația spectacolului, trad. Marin Mălaicu-Hondrari, București, Edit. Humanitas, 2016, p. 228. Decadența culturii prin faptul că orice poate fi considerat ca o formă de cultură, considerarea actului credinței ca fiind doar o formă a culturii sunt evidente în această civilizație a spectacolului.

${ }^{4}$ Horia-Roman PATAPIEVICI, Omul recent, $O$ critică a modernitătii din perspectiva intrebării „ce se pierde atunci când ceva se câștigă?”, București, Edit. Humanitas, 2001, p. 424.

5 IDEM, „Europa și creștinismul”, în Dialogul religiilor în Europa unită, Iulia Badea-Guéritée, Alexandru Ojică (coord.), Tași, Edit. Adenium, 2015, p. 32. Redăm aici un fragment pentru a evidenția nuanțele acestei relații: „Europa depinde de funcționarea în mințile oamenilor (căci civilizația, înainte de a fî un dispozitiv instituțional, exterior, este un dispozitiv mental, la purtător) a acestei noțiuni complexe de transcendentă. Religios și cultural, această noțiune a fost codificată în oameni și instituții prin lucrarea istorică a creștinismului. Într-un sens foarte subtil și profund, Europa și creștinismul sunt una, chiar dacă cele două, ca noțiuni, pot fi gândite separat. Cum am spus la început, Europa este un dar al creștinismului. În același timp, Europa a fost timp de un mileniu corpul material, vizibil, strălucitor, impunător al creștinismului. Corpul are acum o viață a lui, independentă de creștinism. E ca o separare a sufletului de corp sau a corpului de suflet. Va supravieți fiecare? Vor pieri amândouă, și sufletul, și corpul? Se va duce sufletul spre alt corp, într-un proces de metensomatoză istorică? Va primi corpul fără suflet un suflet flotant, unul care deja peregrinează prin istoria contemporană. Nu știu. Nu cred că putem ști".

6 Yuval Noah HARARI, 21 Leçons pour le XXI siecle, traduit de 1'anglais par Pierre-Emmanuel Dauzat, Éditions Albin Michel, 2018, p. 156. 
celui de-Al Doilea Război Mondial, când dezvoltarea tehnică nu cunoscuse încă evoluția din prezent ${ }^{7}$. Critica lui Jean Mouroux se îndreaptă nu împotriva tehnologiei, ci împotriva atitudinii fată de valorile creștine și, mai ales, împotriva filosofiei din spatele utilizării tehnologiei chiar împotriva omului: Homo homini lupus est. $\mathrm{Nu}$ asistăm doar la secularizarea civilizației prin intermediul tehnologiei, ci și la dezumanizarea ei. Această dezumanizare a societății se petrece sub ochii noștri printr-o tehnologizare fără precent ce a determinat ca unele activități să nu mai fie încredințate omului, ci mașinilor inventate de om. Faptul că noile tehnologii ușurează viața omului este incontestabil. Problema este faptul că s-a ajuns ca acestea să înlocuiască multe din activităţile pe care omul le face, ceea ce a determinat o schimbare de paradigmă în activități cheie precum educația, medicina, viața cultică.

\section{Probleme etice ridicate de noile tehnologii}

Matematicianul Preda Mihăilescu remarca faptul că „problemele etice se nasc deja la vârsta grădiniței şi copiii au nevoie de un cadru de referință față de care să se orienteze, în măsura în care acest cadru se angajează să ofere pildele și educaţia în serviciul creșterii deschise a copilului, în primul rând"8. Pandemia Covid19 a adus schimbări majore în actul educațional, predarea făcându-se în anumite perioade și locuri, exclusiv online,

7 „În plus, trebuie să mergem mai departe și să spunem că tot ceea ce omul inventează pentru a se elibera ajunge să-1 înrobească. Cele mai diverse exemple susțin această nefericită lege. Omul inventează un aparat, o mașină; prin ea, omul își prelungește corpul și poate afïrma că își mărește puterea de zece ori. Invenția atenuează sau înlătură unul dintre cele mai grele obstacole, lucru care îl determină pe om să iși afirme stăpânirea asupra universului și astfel își pregătește eliberarea sa. Dar, de fapt, mașina face munca mai inumană ca niciodată; iar progresul mecanic dezlănțuie plăgi fără egal în umanitate, o adevărată sclavie fără nume.", Jean Mouroux, Sens chrétien de l'homme, Paris, Editions Montaigne, Aubier, Quai Conti, 1943, p. 146.

8 Preda MHĂILescu, Și dacă, intr-o zi, Dumnezeu?... Divina Comedie în teoria jocurilor, intre alegerea revelației și alegerea credinței în Dialogul religiilor in Europa unită $\ldots$, p. 365. 
interacțiunea fizică dintre elev, colegi și profesori, lipsind. Rezultatul în Franța a fost o scădere a competențelor elevilor în perioada cât școlile au fost închise în primăvara acestui an ${ }^{9}$.

La nivelul societății din anul 2020, pandemia Covid19 a adus o promovare și aproape o generalizare a ideei de telemuncă, atât ca măsură de precauție, dar și ca schimbare de ritm pentru a putea avea grijă de copilul care învață de acasă. Telemunca aduce cu sine o schimbare a ritmului zilei, a modului de a munci - ședințe cu colegii prin intermediul platformelor online, o schimbare a orarului și chiar a randamentului căci biroul nu mai era la locul de muncă, ci acasă. Tot în același registru se pot menționa și consultaţiile medicale online, cu efecte similare, dar cu o întrebare etică: în ce măsură un medic generalist, spre exemplu, poate pune de la distanță un diagnostic?

Cât despre tehnologia cotidiană din viața noastră se pot aminti doar ședințele online, verificarea unui mail de pe telefon, accesul la internet oriunde etc.. Psihiatrul german Manfred Spitzer vedea o legătură fundamentală între civilizație și ideea de progres, atât la nivel tehnic, cât și științific ${ }^{10}$. Doctorul Spitzer vorbea, de asemenea, despre faptul că smartphone-urile au devenit aproape ca un simbol, o marcă a prezenței Inteligenței Artificiale în viețile noastre. Faptul că sunt utilizate pe scară largă, acceptarea lor în societate nefiind pusă foarte mult sub semnul întrebării, smartphone-urile au bulversat cotidianul umanitătiii ${ }^{11}$. Prezența și

${ }^{9}$ Louise CunEO, Oui, le niveau des élèves de CP et CE1 a baissé avec le confinement, disponibil la https:/www.lepoint.fr/education/oui-le-niveaudes-eleves-de-cp-et-cel-a-baisse-avec-le-confinement-09-11-20202400249_3584.php\# (accesat la data de 9.11.2020).

10 ,Civilizația este legată de progresul tehnic și științific. Ne gândim cu predilecție la ceea ce reprezintă pentru epoca noastră Internetul și cucerirea spațiului; iar atunci când ne uităm în urmă, avem în vedere revoluția industrială, epoca Iluminismului, invenția tiparului sau navigaţia maritimă - și respectiv consecințele lor asupra educației, apărării și organizarea vastelor societăți bazate pe diviziunea muncii (fară de care civilizația este de-a dreptul imposibilă)", Manfred SPITzER, Les ravages des écrans. Les pathologies à l'ère numérique, traduit de l'allemand par Frédéric Joly, Paris, Éditions l'Échappée, 2019 , p. 32.

${ }^{11}$ Ibidem, p. 82. „Viteza cu care smartphone-ul a intrat în viața noastră de zi cu zi, bulversând multe aspecte din viața noastră, este fără precedent, în special în 
dependența de noile tehnologii este în măsură să nască îngrijorări, tot Manfred Spitzer nu ezita să vorbească despre o ,demență digitală" și amintea de faptul că ,în lume s-a impus ideea că biserica ar fi ultimul și totodată cel mai vechi bastion al unor valori precum pacea, familia, iubirea față de copii și sănătatea"12. Este evident că mediile digitale sunt parte a culturii și civilizației noastre, ajutându-ne în diferitele activități cotidiene, atât în productivitate, cât și în partea de divertisment. Dacă pentru moment beneficiile lor sunt evidente din perspectiva performanțelor, îndelunga lor utilizare are ca efecte adicția și treptata incapacitate a omului de a-și folosi propriul corp, abilitățile mentale, stimulii exteriori etc.. În partea de productivitate, la locul de muncă chiar dacă se lucrează de acasă, prin intermediul noilor tehnologii și a mijloacelor de comunicare, treptat s-a ajuns la o constatare: angajatorul se așteaptă ca angajatul să fie la dispoziția sa non-stop, volumul de muncă crescând şi dorința ca răspunsurile la e-mail-uri să fie aproape în timp real ${ }^{13}$.

Aici e una din problemele la care trebuie să răspundă Biserica Ortodoxă nu prin găsirea unui răspuns nou, ci prin

rândul tinerilor care, de la trezire până la culcare, nu se despart niciodată de el. Suntem încă departe de a fi înțeles pe deplin semnificația acestor transformări; în ceea ce privește consecințele lor - de care mulți cercetători sunt interesați în prezent - și mai puțin. Toxicitatea smartphone-ului a fost studiată din punct de vedere științific doar de câțiva ani, iar riscurile pe care le reprezintă și consecințele nu pot fi încă delimitate în totalitate".

${ }^{12}$ IDEM, Demența digitală: cum ne tulbură mintea noile tehnologii, trad. Dana Verescu, București, Edit. Humanitas, 2020, p. 253.

13 „Într-un final, introducerea modalitătilor electronice de comunicare la serviciu a schimbat mai mult decât expectațiile noastre de zi cu zi. Se așteaptă acum, în mare parte, din partea angajaților ca aceștia să răspundă la mesaje în afara programului la fel de rapid ca în cazul mesajelor de la serviciu. În mod esențial, serviciul a devenit, datorită noilor noastre așteptări în ceea ce privește timpul de reacție, o ocupație de douăzeci și patru din douăzeci și patru de ore. Și, așa cum am afirmat înainte, nici măcar vacanțele nu ne mai permit să evadăm acestei cerințe de-a fi "permanent în priză, permanent accesibilì)", Adam GAZZELEy, Larry D. Rosen, Mintea distrată. Creiere vechi într-o lume putermic tehmologizată trad. Ruxandra Vișan, București, Edit. Trei, 2019, p. 186. 
reafirmarea cu tărie a mesajului evanghelic, a îndemnurilor Sfinților Părinți. Dacă din punct de vedere lumesc vorbim de Digital detox, care conform Oxford dictionary este: ,O perioadă de timp în care o persoană se abține de la utilizarea dispozitivelor electronice, cum ar fi smartphone-urile sau computerele, privită ca o oportunitate de a reduce stresul sau de a se concentra asupra interacţiunii sociale în lumea fizică"14, răspunsul părinților filocalici este unul mai actual decât am crede. Spre exemplu, Sfântul Petru Damaschinul, scriitor bizantin din secolul al XI-lea, vorbea despre minte în felul următor: „Căci mintea se preface după forma fiecărui lucru și se colorează după chipul lucrului cunoscut de ea. Iar când se învrednicește să ajungă în Dumnezeu, Cel fără chip și înfățișare, se face și ea fără chip și fără formă" 15 .

În condițile în care vorbim de adicții este evident că rolul medicinei trebuie și el analizat. Unul din cei mai cunoscuți chirurgi și profesori universitari francezi, Guy Vallancien, a pledat într-una din cărțile sale pentru o folosire rațională a tehnologiei în actul medical subliniind că, pe viitor, noile tehnologii vor fi indispensabile în actul medical, dar că aportul lor poate fi benefic $^{16}$, prin faptul că vor defini noile baze ale relației medic-

${ }^{14} \mathrm{https}$ //www.lexico.com/definition/digital_detox (accesat la data de 15.10.2020).

15 Petru Damaschinul, invățături duhoônicești în Filocalia volumul 5, trad. Dumitru Stăniloae, București, Edit. Institutului Biblic și de Misiune al Bisericii Ortodoxe Române, 1976, p. 103.

${ }^{16}$ Potrivit jurământului pe care îl depune în fața colegilor săi, vocația medicului este de a «restabili, păstra sau promova sănătatea în toate elementele sale, fizice și psihice, individuale și sociale». A vindeca omul bolnav și să-1 ajute pe cel sănătos să rămână așa: aceasta este misiunea sa. Pentru a o îndeplini cât mai bine, va avea nevoie tot mai mult de instrumente precum: roboți, inteligența artificială, genomică și nanotehnologie. Aceste instrumente vor fỉ utilizate zilnic, atât pentru a rafina precizia diagnosticului său, cât și pentru a înlesni o decizie terapeutică și realizarea acesteia. De asemenea, va avea nevoie de aceste instrumente pentru a evalua în timp real rezultatele practicilor sale medicale, precum și pentru a organiza armonios acoperirea asistenței medicale și pentru a îmbunătăți procedurile de asigurare și protecție socială. Fără îndoială, inteligența artificială îl va deposeda pe medic de o parte din puterea sa medicală bazată pe cunoaștere; dar îl va elibera în demersul său de recâștigare a esențialului relației, compasiunii și însoțirii omului suferind. În prezent, 
pacient. Această reșezare a dus deja la ideea de medicină preventivă care are un alt obiectiv: pacienții isși vor dori monitorizarea permanentă a stării de sănătate, iar predispozițiile spre o anumită boală să fie depistate încă înainte ca acestea să se manifeste ca o patologie ${ }^{17}$.

Unul din cei mai cunoscuți medici din Franța, doctorul Laurent Alexandre, evidentia încă din 2017 că biotehnologia poate bulversa umanitatea așa cum o știm. Pandemia cauzată de Covid19 arată așadar că chirurgul francez nu s-a înșelat cu privire la Inteligența Artificială, orele de curs din mediul online și în privința digitalizării actului educaţional ${ }^{18}$. Această reconfigurare va avea un

pacienții pot accesa aceleași informații ca și medicii; ceea ce așteaptă de la noi este acest umanism suplimentar în decizia care îi privește personal din cauza experienței noastre", Guy Vallancien, Homo Artificialis. Plaidoyer pour un humanisme numérique, Paris, Michalon Éditeur, 2017, p. 150-151.

17 „Apariția medicinei personalizate și preventive va promova, cu siguranță, dezvoltarea unei noi atitudini a pacienților față de sănătatea lor. În loc să aștepte ca o boală să se declare ca să o tratezi, ei vor începe un proces permanent de gestionare a stării lor biologice. În funcție de predispoziția față de o anumită boală se vor dezvolta strategii de pre tratarea (depistare) lor spre anumite boli, ei vor dezvolta strategii de ,pre-tratament" pentru a preveni apariția patologiei", Laurent ALEXANDRE, Et si nous devenions immortels? Comment la technomédecine va bouleverser l'humanité, Éditions Jean-Claude Lattès, 2011, p. 215.

18 „Odată cu dezvoltarea unor forme mai sofisticate de inteligență artificială, și fără a fi nevoie ca această inteligență să o depășească pe cea a oamenilor, software-ul va putea adapta exact modul în care ajută studenții. Mai mult, tutorialele de mâine vor fi capabile să pună anumite întrebări și să ofere explicații, să prezinte exemple specifice pentru a ilustra principiile abstracte, să folosească testele ca instrument didactic, şi nu ca pe o simplă evaluare. Inteligența Artificială va sprijini apoi profesorul și va ști chiar cum să-1 încurajeze, să fie atent la problemele specifice, să gestioneze ritmul învățării... Pe măsură ce neuroștiințele progresează, adică pe măsură cum înțelegem modul în care creierul uman învață cel mai bine, îmbunătățirea eficienței timpului petrecut în actul de transmitere a cunoștințelor devine posibilă. Adaptarea școlii la noile metode nu va fí ușoară. Pe măsură ce devenim mai capabili să stăpânim neuro-educaţia, tiparul tradițional al școlii „față în față" unde un profesor, într-un fel sau altul, va fi în faţa unui grup de elevi ore întregi, va părea contraproductiv. Așa cum spune John Medina, «Dacă ați dori să creați un mediu educațional care să fie direct opus modului 
impact și la nivelul personal al fiecărui om ce beneficiază de acces la noile tehnologii. Trebuie mentionat faptul că doctorul Laurent Alexandre este unul din cei mai cunoscuți medici transhumaniști care, totuși, se delimitează de ideea unui postumanism ${ }^{19}$. Viața duhovnicească ar putea avea un folos de pe urma acestei utilizări, adeseori exagerate, după cum sublinia arhidiaconul Sorin Mihalache $^{20}$. Așadar, noile tehnologii au un impact concret asupra propriei persoane cu reale implicați în viața cotidiană și în cea duhovnicească. Într-un articol din 2015 despre inteligența artificială din săptămânalul francez L'Express, se arată faptul că noile tehnologii vor evidenția slăbiciunile omului și vor exista voci care vor milita pentru o nouă ,necesitate”, aceea de a-și încredința parte

în care funcţionează creierul, probabil că aţi proiecta ceva care să fie ca o clasă». Neuroeducația va marca reconfigurarea completă a clasei așa cum o cunoaștem astăzi", Laurent ALEXANDRE, La guerre des intelligences. Comment l'intelligence artificielle va révolutionner l'éducation, Éditions Jean-Claude Lattès, 2017, p. 188-189.

${ }^{19}$ Jean Boвоc, Le Transhumanisme décrypté. Métamorphose du bateau de Thésée. Essai sur le transhumanisme, Éditions Apopsix, 2017, p. 23.

20 ,În utilizarea dispozitivelor tehnice pentru monitorizarea vieții, în parametri biologici tot mai fini, se poate întrevedea, în mod simbolic, un rest al îngrijirii de sine, reflexul unei vocații omenești de autotranscendere, în expresia cea mai adecvată a culturii senzoriale în care trăim. Aceste dispozitive de monitorizare a vieții, alături de toate celelalte gadgeturi care oferă posibilitatea autoînregistrării și fotografierii (selfie), ar putea fi văzute ca o oglindă artificială, folosită pentru surprinderea propriului subiect. Aceste preocupari întoarse către sine ar putea scoate la iveală un anumit defícit de autocunoaștere și de autocontrol, care vine în urma unei înstrăinări a omului față de propriul univers lăuntric, de locul de unde izvorăsc mișcări pe care el nu le cunoaște îndeajuns de bine și nu știe sau nu poate să le controleze. S-ar putea ca aceasta să se petreacă tocmai pentru ca exercițul tradițional al ascezei, perfect adaptat persoanei, specific vieții spirituale, mod de cultivare a voinței și de deprindere a autocontrolului, deopotrivă cu exercițiul supravegherii de sine, nu-i mai sunt familiare", Adrian Sorin Murialache, Ești ceea ce trăiești. Câteva date recente din neuroștiințe și experiențele duhovnicești ale Filocaliei, Ediția a II-a revizuită și adăugită, Colecția Media Christiana, Seria Lumina, București, Edit. Trinitas a Patriarhiei Române, 2019, p. 359. 
din capacitățile sale unui computer ${ }^{21}$. Dar pentru ca noile tehnologii să ajute concret și în viața duhovnicească, utilizarea lor trebuie să nu afecteze comportamentul și modul de a fi al unui creștin. Concret vorbind, ele nu ar trebui să împiedice asceza, autocontrolul, controlul gândurilor etc..

Faptul că trăim într-o civilizație și o cultură a datelor reglementată pe Internet, în Uniunea Europeană, printr-un regulament general privind protecția datelor este unul evident. $\mathrm{Nu}$ este de ignorat nici faptul că indicatorii performanței ne însoțesc în viața de zi cu zi și încearcă să se transpună și la nivel spiritual. Însă, desăvârșirea nu trebuie înțeleasă în aceeași termeni ca progresul din viața cotidiană. Ar fi greșit să credem că în viața duhovnicească creștinul nu trebuie să progreseze. Dimpotrivă, desăvârșirea nu este doar un deziderat, ci vocația la care omul a fost chemat (Matei 5, 48). De asemenea, imaginea celui care se luptă respectând regulile jocului pentru a dobândi cununa (2 Timotei 2,5$)$ este elocventă pentru a afirma că progresul în viața duhovnicească este necesar. Sfântul Macarie Egipteanul considera că „,nu abținerea de la relele cele văzute aduce desăvârșirea, ci curăția minții, aceasta echivalează cu desăvârșirea"22. Sfântul Grigorie de Nyssa înțelegea desăvârşirea ca fiind legătura strânsă a creștinului cu Hristos: „Aceasta însemnează, dupa părerea mea, desăvârșirea vieții creștine ce se arată prin toate numirile care sunt cuprinse în cuvântul Hristos: a avea o legătură strânsă cu Hristos în suflet, în vorbă ca și

21 „Omul este incomplet, incapabil să analizeze consecințele a ceea ce face. Calculatorul, din contră, va implementa toate consecințele celor scrise. Dacă vreodată în lanțul consecințelor va exista ceva care nu ar trebui să fie acolo, omul nu va observa acest lucru pe când un calculator va răzbi. Acesta este „bug-ul”'. Un om nu este capabil să tragă consecințele acțiunilor sale la scara a miliarde de instrucțiuni. Or, acest lucrul îl va face programul, va executa miliarde de instrucțiuni", Raphaële KARAYAN, Intelligence artificielle: attention danger, même Bill Gates a peur!, L'Express, 2 février 2015, disponibil la https://lexpansion.lexpress.fr/high-tech/intelligence-artificielle-attention-dangermeme-bill-gates-a-peur_1647411.html (accesat la data de 23.06.2020).

22 Sfầntul Macare EgIPTEAnut, Despre inălțarea minții, 20, trad. Constantin Cornițescu, introducere, note și indici de N. Chițescu în „Omilii duhovnicești”, colecția Părinți și Scriitori Bisericești, vol. 34, București, Edit. Institutului Biblic și de Misiune al Bisericii Ortodoxe Române, 1992, p. 323. 
în toate ocupațiile vieții, ca să păstrăm întreagă asupra noastră, după binecuvântarea Sfântului Apostol Pavel, sfințenia în tot trupul, în tot sufletul și duhul, rămânând continuu în afară de orice amestecare cu răul"23.

Revenind, practic, în momentul de față mizele accesului la datele pacienților sunt enorme, cel puțin pentru a oferi un exemplu din domeniul medical ${ }^{24}$. Iar acest domeniu nu este singurul în care se duce o veritabilă bătălie pe datele fiecărui om. Nu ne mărginim doar la datele personale, căci pentru modelul economic al societății actuale ce se bazează pe un veritabil detector de dorințe ${ }^{25}$ sunt

${ }^{23}$ Sfầntul GRIGORIE DE NYSSA, Despre desăvârșiire, către monahul Olimpiu, trad. Teodor Bodogae în Sfântul Grigorie de Nyssa, „Scrieri - partea a doua”, colecția Părinți şi Scriitori Bisericești, vol. 30, București, Edit. Institutului Biblic și de Misiune al Bisericii Ortodoxe Române, 1998, p. 476.

24 „Din surse multiple și variate, datele clinice, genomice, fenotipice și epidemiologice colectate de la fiecare pacient fac posibilă personalizarea îngrijirii fiecărui pacient; tratamentul, utilizarea și analiza acestor date sunt provocări majore pentru oncologia viitorului. În timp ce accesul la un volum mare de date de calitate este una din mizele majore ale performanței Inteligenței Artificiale, sectorul sănătății francez se află într-o situație paradoxală: mai numeroase decât în alte țări, aceste date sunt în același timp mai puțin accesibile, consecință a unei legislații europene stricte care limitează exploatarea lor. Legi considerate „suverane” de către unii medici și cercetători, care în această lume foarte competitivă, încetinesc progresul muncii lor. Un alt paradox, care cuprinde întreg continentul: deși datele lor personale sunt mai bine protejate de legi, iar nerespectarea consimțământului liber și clar al fiecărui pacient atrage după sine sancțiuni majore, europenii sunt cei care se arată cei mai îngrijorați de utilizarea datelor lor", Astra ZENECA, L'intelligence artificielle. Une alliée de taille dans la lutte contre le cancer, Sciences et Avenir, mars 2020, p. 95.

25 „Mulțumită cantităților astronomice de date pe care le cuprind, în special prin intermediul rețelelor de socializare, aceste companii ne cunosc gusturile, obiceiurile, comportamentul, dorințele... în această lume a noastră foarte consumistă, Inteligența Artificială este folosită ca un veritabil detector de dorințe. Ea trimite de îndată în mod specific argumentele care ne vor seduce. Este pârghia recompensei. Ni se adresează în mod personal fiecăruia dintre noi, țintit pe fiecare individ în parte, în funcție de ceea ce știe despre ei. În curând vom avea, dimineața, câte un ziar personalizat, cu informații legate doar de ceea ce nouă ne place. În China, în unele companii de fast-food, există aplicaţii care recunosc clientul de îndată ce acesta se apropie și îi propun imediat un meniu personalizat. Dacă zâmbește, zâmbetul înseamnă 
suficiente într-o primă fază informațiile de pe rețelele de socializare, publicitate, activități, produse căutate pe internet etc..

\section{Reacția Bisericii Ortodoxe și posibile soluții}

Cum a răspuns Biserica Ortodoxă acestor provocări? În primul rând, în cazul României trebuie subliniată relaţia dintre stat și culte. „Sistemul românesc al relațiilor dintre culte și stat se înscrie pe coordonatele generale ale modelului european, prin prioritatea acordată libertăți religioase, autonomiei și libertății de acțiune generală a cultelor în spațiul public" "26, amintea Secretariatul de Stat pentru culte în 2014. Relația aceasta nu a mai funcționat, după cum lesne s-a putut vedea. În ciuda restrictiilor la care a fost supusă, implicarea Patriarhiei Române în acte de filantropie a fost una concretă, de o mare amploare, tocmai în anul comemorativ al filantropilor ortodocși români ${ }^{27}$. Pe de altă parte, nu doar în România, ci în întrega Europă relația stat-biserică a suferit unele mutații. Răspunsuri, la nivel ecumenic, pot fi găsite. Astfel, unele grupuri tematice din cadrul Conferintei Bisericilor Europene au oferit texte în care semnalau unele carențe ale relației dintre biserici și statele naționale pe fondul restricțiilor impuse în primăvara

acceptarea comenzii, iar plata se efectuează automat. Inteligența artificială reprezintă o adevărată intruziune în viața intimă. Modelele economice se bazează acum pe această utilizare a datelor", Jean-Gabriel GANASCIA, „L'IA est utilisée comme un véritable détecteur de désirs", în Sciences et Avenir (hors-série), octobre/novembre 2019, p. 22.

26 Victor OpASCHI, Statul și cultele religioase în România: un model european în Dialogul religiilor în Europa unită..., p. 278.

27 În pastorala Sfântului Sinod al Bisericii Ortodoxe Române la prima duminică a postului Nașterii Domnului 2020 este amintit faptul că: „opera socialfillantropică a Bisericii este inspirată din lucrarea filantropică, vindecătoare, sfințitoare şi mântuitoare a Domnului nostru Iisus Hristos şi are, totodată, o profundă dimensiune pastorală, exprimând o credință lucrătoare prin iubire darnică și contribuind la cultivarea comuniunii cu Dumnezeu și cu semenii, adică la dezvoltarea unei culturi a dărniciei sau a generozităţii". Text disponibil la https:/basilica.ro/wp-content/uploads/2020/11/Pastorala-laprima-duminica-din-Postul-Nasterii-Domnului-2020.pdf p. 5 (accesat la data de 12.11.2020) 
anului 2020. Membrii grupul tematic pentru Știință, Noile Tehnologii și Etici creștine evidențiau următoarele: „Pentru unele traditii, aceasta poate fi o oportunitate de a găsi noi forme de celebrare a Euharistiei utilizând comunicarea digitală. Alții suferă pentru că, în traditia lor, este de neconceput să slujească și să primească Sfânta Împărtășanie, în afara unei adunări fizice a credincioșilor. Rămânând fidelă practicii lor vechi de secole, aceste vremuri extraordinare pot fi înțelese și trăite și ca o chemare la creativitate inspirată" ${ }^{28}$. La rândul lor, membrii din grupul tematic pentru Educație, Democrație și Diversitate considerau că bisericile nu trebuie să fie în poziția de spectatori în schimbările prin care trece societatea europeană și mondială, ci tradiția creștină trebuie să fie folosită în construirea Europei juste și unificate social ${ }^{29}$.

În cadrul unui webinar organizat de grupul de lucru al Partidului Popular European, în 24 iunie 2020, cu titlul The impact of COVID-19 pandemic on Churches. Churches' Social Teachings in response to COVID - EPP webinar, Comitetul Reprezentanților Bisericilor Ortodoxe pe lângă Uniunea Europeană (CROCEU), prin părintele George Vâlcu, a evidențiat problemele cu care Biserica

${ }^{28}$ Reflections on Christian Communion in a Time of Physical Distancing and COVID-19 Reflections offered by members of the CEC Thematic Group on Science, New Technologies and Christian Ethics in view of the Easter celebrations in our Churches amidst COVID-19 crisis. https:// www.ceceurope.org/wp-content/uploads/2020/04/Reflections-Virtualworshipping-final-version.pdf p. 2 (accesat la data de 10.11.2020).

29 ,Actuala criză nu se va încheia de pe o zi pe alta. Cu toate că nu cunoaștem încă amploarea acestei crize, suntem chemați să reflectăm la ziua de mâine. Speranța la «noul Ierusalim »nu ne permite să fim simpli spectatori. Dimpotrivă, ca Biserici, ar trebui să contribuim activ la modelarea viitorului Europei. Aceasta include o discuție sinceră și deschisă în Bisericile noastre, într-un spirit fratern, care ia în considerare marile provocări legate de construirea unei Europe juste și unificate social. Trăim speranța creștină că «Dumnezeu face toate lucrurile noi». Speranța noastră ne unește și ne încurajează să împărtășim și să contribuim la o lume mai dreaptă prin tradiția noastră creștină, prin experiența noastră de democrație și prin punerea în valoare a drepturilor omului", https://www.ceceurope.org/wp-content/ uploads/2020/06/TG-EDU-reflections-Covid19_RO.pdf p. 2 (accesat la data de 5.11.2020). 
Ortodoxă din Uniunea Europeană s-a confruntat. Relația statbiserică este și ea semnalată prin faptul că statul a decis aproape în mod unilateral care sunt activitățile care sunt esențiale pentru societate $^{30}$.

Dacă am face apel la Sfinții Părinți pentru a găsi un răspuns la problemele cu care Biserica, cler și credincioși se confruntă, aceștia ar îndemna, cu siguranță, la cunoașterea de sine, la discernământ. În acest sens, Sfântul Grigorie de Nyssa fãcea apel la cunoașterea realităților ce ne înconjoară și la buna cumpănire a lucrurilor $^{31}$. O soluție pentru problemele bioetice îndeosebi este indicată de părintele Jean Boboc: „Sfințenia, constituţia, natura

30 „Cum anume determină statul care activităţi sunt esențiale pentru societate și care nu? Are statul autoritatea de a decide asupra acestei chestiuni pentru toți cetățenii săi? Și, atunci când statul decide că religia nu este esențială pentru viața cuiva, nu cumva statul devine organ al unei abordări seculariste asupra vieții și societății în detrimentul uneia religioase? $\mathrm{Nu}$ aceasta este exact versiunea opusă a pericolului de care secularismul însuși declară că vrea să ne protejeze, adică acordarea altcuiva a dreptului meu de a decide ce să cred?", Rev. George Vâlcu, CROCEU General Secretary. Text disponibil în limba engleză la adresa: https://c91f778a-eebb-4276-b349-61560f171a0e. filesusr.com/ugd/b99d55_05805c43d8cb43ff9209f44a268b79ff.pdf (accesat la data de 1.11.2020).

31 „Cel mai sigur mijloc de a ne păzi pe noi este să nu fim în neștiință, nici să nu ne socotim că ne vedem pe noi înșine când vedem ceva din jurul nostru. Aceasta o pătesc cei ce din lipsă de luare aminte la ei înșiși, văzând în tărie, sau frumusețe, sau slavă, sau putere, sau belșug de bogăție, sau mândrie, sau îngâmfare, sau mărimea trupului, sau frumusețea chipului, sau altceva de felul acesta, socotesc că ei înșiși sunt așa. De aceea, sunt niște paznici nesiguri ai lor, lăsând fără pază ceea ce le e propriu, prin dragostea de ceea ce le e străin. Căci cum ar păzi cineva ceea ce nu cunoaște? Deci cea mai nesigură străjuire a bunătăților din noi e să nu fim neștiutori de noi înșine, ci să se cunoască fiecare pe sine ca ceea ce este și să se deosebească pe sine de cele din jurul său, ca să nu se afle păzind, în loc de sinea sa, ceea ce-i străin. Căci cel ce privește spre viața din lumea aceasta și socotește cele de aici vrednice de pază, nu știe să deosebească ceea ce îi este propriu, de ceea ce e străin", Sfântul GRIGORIE DE NYSSA, Tâlcuire amămuntită la Cântarea Cântărilor, Omilia a II-a, trad. Dumitru Stăniloae și Ioan Buga, note: Dumitru Stăniloae, indice: Ioan Buga, în colecția Părinți și Scriitori Bisericești, vol. 29, București, Edit. Institutului Biblic și de Misiune al Bisericii Ortodoxe Române, 1982, p. 141. 
umană, condiția umană și demnitatea universală sunt elementele de bază ale reconstrucției. Toate acestea formează un soclu solid al reflecției morale și etice pe care se poate construi un pachet de argumente care permit combaterea tezelor revoluționare ce subminează natura și omul"32. Tot în această cheie a soluțiilor se înscrie și gândul părintelui Marc-Antoine Costa de Beauregard care susținea încă din 2015 că Biserica Ortodoxă trebuie să-și continue misiunea în ciuda tuturor piedicilor ce le întâmpină și le va întâmpina și în viitor ${ }^{33}$.

Pandemia cauzată de Covid19 a acutizat și evidențiat dependența omului de noile tehnologii și a arătat că cultul Bisericii poate fi înțeles de către stat ca fiind o celebrare, în fața camerei doar din partea clericilor, fără prezența credincioșilor, aceștia din urmă fiind considerați simpli beneficiari. Liturghia nu a mai fost o slujbă pentru popor, o împreună slujire, ci în viziunea statului, cultul a fost identificat $\mathrm{cu}$ o prestare de servicii nonesențiale. Întrebarea de la început: Care mai e rolul unei Biserici în societate din moment ce nu își poate primi credincioșii la slujbă? își găsește răspunsul în atitudinea pe care Biserica Ortodoxă trebuie să o aibă față de ideologiile societății contemporane, îndeosebi transumanismele și laicitatea care încearcă să se impună ca o nouă religie. $\mathrm{Nu}$ în ultimul rând, relația dintre stat și Biserica Ortodoxă va trebui regândită întrucât s-a dovedit faptul că abordarea statului în ceea ce privește libertatea religioasă - drept fundamental indiferent de vicisitudinile istorice a fost una de privare a cetățenilor săi de acest drept. Slujirea Sfintei Liturghii în prezența credincioșilor este și trebuie să fie un act de mărturisire a credinței

32 Jean Bовос, Le Transhumanisme décrypté..., p. 328-329.

33 „Chiar dacă, fiind realiști, am ști că s-ar putea ca bisericile să fie distruse, icoanele arse, copiii persecutați și obligați poate să devină musulmani, trebuie să continuăm să construim, să pictăm icoane, să facem copii şi să-i botezăm creștini, să nu abandonăm, căci altfel nu am mai fi oameni și nu neam mai putea lupta în numele credinței, nu am mai putea să-L privim în față pe Dumnezeu. Nu am mai fi demni să-L privim. Dacă am abandona și n-am mai putea să-L privim în ochi totul ar fi foarte, foarte trist", Marc-Antoine Costa de Beauregard, "Timpul Bisericilor nu a trecut”, în Dialogul religiilor în Europa unită..., p. 253. 
în Hristos Domnul, Biruitorul morții. De remarcat este faptul că una din învierile relatate în cartea Faptele Apostolilor, Învierea lui Eutihie (Faptele Apostolilor 20, 7-12) a avut loc tocmai în contextul slujirii euharistice ${ }^{34}$.

$\cos 8$

\section{Bibliografie}

1. ALEXANDRE, Laurent, Et si nous devenions immortels? Comment la technomédecine va bouleverser l'humanité, Éditions JeanClaude Lattès, 2011.

2. IDEM, La guerre des intelligences. Comment l'intelligence artificielle va révolutionner l'éducation, Éditions Jean-Claude Lattès, 2017.

3. BADEA-GUÉRITÉE, Iulia / OIICĂ, Alexandru (coord.), Dialogul religiilor în Europa unită, Iași, Edit. Adenium, 2015.

4. BoBOc, Jean, Le Transhumanisme décrypté. Métamorphose du bateau de Thésée. Essai sur le transhumanisme, Editions Apopsix, 2017.

5. GANASCIA, Jean-Gabriel, „L'IA est utilisée comme un véritable détecteur de désirs", în Sciences et Avenir (hors-série), octobre/novembre 2019.

6. Gazzeley, Adam / Rosen, Larry D., Mintea distrată. Creiere vechi intr-o lume puternic tehnologizată, trad. Ruxandra Vișan, București, Edit. Trei, 2019.

7. Grelot, Pierre, Sens chrétien de l'Ancien Testament. Esquisse d'un traité dogmatique, $2^{\mathrm{e}}$ édition, revue et corrigée, Paris, Éditions Desclée et Cie, 1962.

8. Sfântul GRIGORIE DE NYSSA, Despre desăvârșire, către monahul Olimpiu, trad. Teodor Bodogae în „Scrieri - partea a doua”, colecția

34 „Episodul învierii lui Eutihie a fost inclus în acest context euharistic pentru a arăta și aminti că de fiecare dată când se săvârșește Euharistia se celebrează Hristos Înviat prezent în Biserica Sa în care-și manifestă puterea, ca să-i păzească pe credincioșii Săi de puterile Celui Rău și ale morții", Constantin PREDA, „Frângerea pâinii la Troa și Învierea lui Eutihie” în Studii Teologice, 1-2/1999, p. 124. 
Părinți și Scriitori Bisericești, vol. 30, București, Edit. Institutului Biblic și de Misiune al Bisericii Ortodoxe Române, 1998.

9. IDEM, Tâlcuire amănunțită la Cântarea Cântărilor, Omilia a II-a, trad. Dumitru Stăniloae și Ioan Buga, note Dumitru Stăniloae, indice Ioan Buga, în colecția Părinți și Scriitori Bisericești, vol. 29, București, Edit. Institutului Biblic și de Misiune al Bisericii Ortodoxe Române, 1982.

10. HARARI, Yuval Noah, 21 Leçons pour le XXI siècle, traduit de l'anglais par Pierre-Emmanuel Dauzat, Éditions Albin Michel, 2018 .

11. IONIȚĂ, Viorel, Hotărârile întrunirilor panortodoxe din 1923 până in 2009. Spre Sfântul și Marele Sinod al Bisericii Ortodoxe, București, Edit. Basilica a Patriarhiei Române, 2013.

12. IDEM, Sfântul și Marele Sinod al Bisericii Ortodoxe - Documente pregătitoare, București, Edit. Basilica a Patriarhiei Române, 2016.

13. Sfântul MACARIE EGIPTEANUL, Despre înălțarea minții, 20, trad. Constantin Cornițescu, introducere, note și indici de N. Chițescu în „Omilii duhovnicești”, colecția Părinți și Scriitori Bisericești, vol. 34, Edit. Institutului Biblic și de Misiune al Bisericii Ortodoxe Române, București, 1992.

14. MiHALACHE, Adrian Sorin, Essti ceea ce trăiești. Câteva date recente din neuroștiințe și experientele duhovnicesti ale Filocaliei, Ediția a II-a revizuită și adăugită, Colecția Media Christiana, Seria Lumina, București, Edit. Trinitas a Patriarhiei Române, 2019.

15. Mouroux, Jean, Sens chrétien de l'homme, Paris, Editions Montaigne, Aubier, Quai Conti, 1943.

16. PATAPIEVICI, Horia-Roman, Omul recent, $O$ critică a modernităţii din perspectiva intrebării „ce se pierde atunci când ceva se câştigă?", București, Edit. Humanitas, 2001.

17. *** Pentru viața lumii. Către un ethos social al Bisericii Ortodoxe: invățătura socială a Bisericii Ortodoxe în viziunea Patriarhiei Ecumenice, trad. Viorel Coman şi Petre Maican, Oradea, Edit. Ratio et Revelatio, 2020.

18. PETRU DamaschinUl, Invățături duhovnicești în Filocalia volumul 5, trad. Dumitru Stăniloae, București, Edit. Institutului Biblic și de Misiune al Bisericii Ortodoxe Române, 1976.

19. PREDA, Constantin, „Frângerea pâinii la Troa și Învierea lui Eutihie" în Studii Teologice, seria a II-a, 1-2/1999. 
20. SPITEZER, Manfred, Demența digitală: cum ne tulbură mintea noile tehnologii, trad. Dana Verescu, București, Edit. Humanitas, 2020.

21. IDEM, Les ravages des écrans. Les pathologies à l'ère numérique, traduit de l'allemand par Frédéric Joly, Paris, Éditions l'Échappée, 2019.

22. Vallancien, Guy, Homo Artificialis. Plaidoyer pour un humanisme numérique, Paris, Michalon Éditeur, 2017.

23. ZENECA, Astra, „L'intelligence artificielle. Une alliée de taille dans la lutte contre le cancer", în Sciences et Avenir, mars 2020. 